Article

\title{
Social Inclusion through Community Living: Current Situation, Advances and Gaps in Policy, Practice and Research
}

\author{
Jan Šiška ${ }^{1, *}$, Julie Beadle-Brown ${ }^{2}$, Šárka Káňová ${ }^{3}$ and Pavlína Šumníková ${ }^{1}$ \\ ${ }^{1}$ Faculty of Education, Charles University, 11639 Prague, Czech Republic; E-Mails: jan.siska@pedf.cuni.cz (J.Š.), \\ pavlina.sumnikova@pedf.cuni.cz (P.Š.) \\ 2 Tizard Centre, University of Kent, Canterbury, Kent, CT2 7LR, UK; E-Mail: j.d.beadle-brown@kent.ac.uk \\ ${ }^{3}$ Faculty of Education, University of West Bohemia, 30100 Pilsen, Czech Republic; E-Mail: kanova@kpg.zcu.cz \\ * Corresponding author
}

Submitted: 2 October 2017 | Accepted: 14 February 2018 | Published: 26 March 2018

\begin{abstract}
This article draws on the findings of the EU Framework 7 project DISCIT to explore the living situation of people with disabilities a decade after the adoption of the UN Convention on the Rights of Persons with Disabilities in nine European countries representing different welfare state models and different stages in the process of deinstitutionalisation. A review of the research literature, policy and available statistics was combined with interviews with key informants in each country to explore the current living situation, changes over time and the barriers to, and facilitators for change. The article focuses in particular on whether people are experiencing opportunities for social inclusion on an equal basis with others. Although a lack of available data hampered conclusions on living situation, it was clear that there had been some change in terms of policy and funding streams available to support community living. Some countries had moved slightly towards community living, while others reported more people in institutions or the development of bigger services in the community. There was evidence of continued inequality in the living situation and full inclusion of people with disabilities, with those with intellectual disability and psychosocial disabilities being the most affected. In terms of barriers (and consequently facilitators) there were three sources: 1) policy, 2) social care and support systems, and 3) awareness, attitudes and advocacy. The need to involve people with disabilities in policymaking and the need for a co-ordinated approach between all actors in the disability sector was seen as critical for achieving further change.
\end{abstract}

\section{Keywords}

community living; disability; inclusion; policy

\section{Issue}

This article is part of the issue "Disability Equality: In Theory and Practice", edited by Mark Priestley (University of Leeds, UK) and Lisa Waddington (Maastricht University, The Netherlands).

(C) 2018 by the authors; licensee Cogitatio (Lisbon, Portugal). This article is licensed under a Creative Commons Attribution 4.0 International License (CC BY).

\section{Introduction}

Social inclusion has long been considered a key element of quality of life (see, for example, Schalock et al., 2002) and is intrinsically related to many other key concepts such as (active) citizenship (DISCIT, 2013). In order to have full and meaningful inclusion in your local community and in society more generally, you need to have presence in that community, feel part of that commu- nity and to be actively participating in, and contributing to, that community (O'Brien, 1987; Mansell \& BeadleBrown, 2012; Miller \& Katz, 2002). The latter is sometimes referred to as having "a valued role" (Wolfensberger, 2000).

The importance of both presence in the community and active participation is echoed in the UN Convention on the Rights of Persons with Disabilities (UN CRPD; United Nations, 2006), in particular in Articles 19, 29 and 
30. Article 19 gives people with disabilities the right to a home in the community like everyone else, choice over their living situation and support for full inclusion and participation in the community. Article 29 affords people the right to participation in political and public life while Article 30 outlines the right to participation in cultural life, recreation, leisure and sports. However, living situation, participation in all aspects of community life, having choice and autonomy, is not just to be made available but to be done so on an equal basis with others. In addition, having support as needed to exercise these rights is also a critical concept throughout the Convention, thus emphasising the importance of equality (as opposed to equity). For example, Article 19 uses "with choices equal to others", "opportunity to choose their place of residence and where and with whom they live on an equal basis with others" and "Community services and facilities for the general population are available on an equal basis to persons with disabilities".

The 2017 general comment on Article 19 (Committee on the Rights of Persons with Disabilities, 2017, para. 13) reminds us that the principles of equality and non-discrimination are core to all human rights instruments and that even in 1994 the Committee on Economic, Social and Cultural Rights highlighted that "segregation and isolation through the imposition of social barriers" counts as discrimination". As argued prior to the UN CPRD (e.g., by Rosenthal \& Kanter, 2002), institutionalisation deprives people of their right to live as equal citizens in the community by imposing both physical and social barriers. This article will focus on community living as the first step to full inclusion and participation in the community and to achieving true equality.

The early definitions of "community care" such as those put forward by the King's Fund and the Ordinary Life programme in the UK (King's Fund, 1980) were very similar to the concepts now enscribed in the UN CRPD. The vision of community care was set out as:

- Using accommodation located among the rest of the population, which is adequate, appropriate and accessible to the individual;

- Using the range of accommodation options ordinarily available to the wider population;

- Enabling people, to the greatest extent possible, to choose where, with whom and how they live;

- Providing whatever help is required to enable people to participate successfully in the community.

It is important to note that even here, the idea of equality was implicit in the definition of community living-it is about making the same range of accommodation options available to people with disabilities as to everyone else.

More recently, the vision of community-based services has come to refer to a model where there is separation of support from the provision of accommodation (sometimes called "Supported Living", (Allard, 1996; Kinsella, 1993; Stevens, 2004). Support is provided to people within their own home (rented or owned). In this model, people are also usually involved in planning their support, such as where they live, who supports them and how support is provided. Overall, these services are intended to support people to live as full citizens rather than expecting people to fit into standardised models or structures. For the most part, this model of communitybased support is achieved through the availability of personal budgets and personal assistance.

The current article draws on findings from a European Commission Framework 7 project on active citizenship for people with disabilities (DISCIT) ${ }^{1}$ across nine countries. The nine countries represent different areas of Europe, different welfare state models (EspingAndersen, 1990; Deacon, 1993) and are at different stages in the process of developing community-based services for people with disabilities: Norway and Sweden (Socio-democratic welfare state model); Germany and Italy (conservative/corporatist welfare state model); UK and Ireland (Anglo-Saxon/Liberal welfare state model; and Czech Republic and Serbia (post-communist and developing welfare state models). This article is the first in a series looking at the living situation and community participation of people with a disability one decade after the adoption of the UN CRPD and a decade on from the publication of the report from the European Commission funded project on the outcomes and costs of Deinstitutionalisation and Community Living (DECLOC). The latter report identified that at least one million people with disabilities were living in institutions in Europe, with this being a substantial underestimate (Mansell, Knapp, Beadle-Brown, \& Beecham, 2007). This article aims to 1) map what is already known about the living situation and inclusion of people with disabilities (and whether they have choice in particular over their living situation) through existing research, official statistics and from those working in the field in each country, and 2) identify barriers and facilitators to achieving widespread community living.

\section{Methodology}

\subsection{Part 1: Review of Existing Information, Policy and Research}

Existing sources of data in each country were collated and reviewed in 2014-2015 by the research team from each country to identify and collate relevant material using a template to ensure consistency in the data collated. Sources included government statistics and publications, legislation and other policy, publications by NGOs and DPOs and academic research. The type of data collated included (where available): prevalence of disability in the countries; policies and systems supporting the develop-

\footnotetext{
${ }^{1}$ SP1-Cooperation, Social Sciences and Humanities (SSH) - Collaborative project - small or medium-scale focused research project FP7-SSH2012-2 SSH.2012.3.2-2 - Grant Agreement Number 320079.
} 
ment of community-based support; the nature of accommodation and support services that exist in each country and the number of people in a range of different living situations; progress towards the closure of institutional services; information on choice of living situation and support; any information on how people with disabilities participate in their local community, access community facilities and events and whether they receive support to do so; and recognised barriers and threats to community living. In terms of type of accommodation services available, researchers were asked to describe the services in terms of size, form and organisation, staffing, location, and population served. Based on this information, accommodation services were coded by the authors into the following categories:

- Small groups homes (<10 places)-usually 24hour support;

- Apartment with support provided by/funded by state, etc.- usually less than 24-hour support;

- Own home (rented/owned) with assistance (up to 24 hours);

- Larger residential home (10 or more but less than 30 places);

- Institution (30 places or more).

Sources of all the data included in the template were also provided for each country and data were examined to assess, as far as possible, its internal consistency and any inconsistencies between different sources.

\subsection{Informant Interviews}

A series of semi-structured interviews were conducted with informants who were judged to have some expertise or knowledge around disabilities issues. Eighty-four informants were interviewed across the nine countries. Those interviewed included: representatives of innovative community-based services and organisations, including disabled people organisations (DPOs); representatives from official or government positions at national, federal/regional and local level; academics; and disabled people themselves.

Reports from each interview were prepared in English and 36 of these informants (four from each of the nine countries) who could comment on community living aspects specifically were selected for detailed analysis. Of those for whom data on characteristics were available: $50 \%$ were male; $61 \%$ were from DPO or NGOs $(25 \%$ from NGOs and the remainder were from DPOs, including those who themselves had a disability); three people classified themselves as disability activists; $65 \%$ worked at a national level.

The reports from the interviews were thematically analysed and initially coded for the following topics, paying attention to variation by disability group or geographic location:
- Current situation of people with disabilities and the support received;

- Changes in situation over time;

- Barriers to the development of community living;

- Facilitators of the development of community living;

- What is needed for successful development of community living in this country?

Under each of these topics, overarching themes and subthemes were identified. Three members of the lead research team for the DISCIT work package focusing on community living read and coded the reports and all the themes and sub themes were then collated in one document (preserving the identification by country). Any additional points that did not fit into one of the initial themes were also recorded along with quotations that might be useful for illustrating key points. The second author then collated all the subthemes for final synthesis. For the topics where most information was available (i.e., barriers and facilitators) the themes and subthemes were summarised diagrammatically. These diagrams also give an indication of which themes were identified in each country. It is important to note that if an issue was mentioned by even one informant within a country it was included. However, different informants in the same countries often raised the similar themes. We have not identified which interviewers made which points but rather we have collated the main findings from across the interviews. Interestingly, contradictory reports between informants within each country were not found, although of course opinions and perspectives on the situation did vary. Any quotations provided are for illustrative purposes only.

\section{Findings}

3.1. What Do We Know About Living Situation of People with Disabilities and How Has It Changed in the Past 10 Years?

As in previous research (Mansell et al., 2007) the completeness and quality of the data available was a substantial issue. Even when information was available on the number of people receiving a service, information on the size and/or nature of those services were not always available. In other cases, the data is only on the number of places in a setting, not how many people are actually living there. In some countries, the name of a service could potentially be misleading-for example, in the Czech Republic large residential provisions were officially named 'institutions' up to 2006. Due to legislative changes, the same settings are now named 'homes for people with disabilities', but with no indication of whether those living there had experienced any change. This is similar to what had been observed in Denmark and Finland (Tøssebro et al., 2012). 
The figures reported in Table 1 below are therefore presented with caution and as illustrative rather than definitive.

The available statistical data indicated that services for more than 30 people still existed in all nine countries but with differences between the countries and across disability groups. For example, Sweden only has larger establishments in the form of acute services for people with mental health problems and in Norway and Sweden only a small number of people with severe or multiple physical disabilities live in larger establishments, although in both countries, a recent trend towards bigger or more clustered settings had been reported (Tøssebro et al., 2012). In the UK, although current policy seeks to change this, there is still a tendency for some people with intellectual disability (ID) and/or autism (in particular those who have displayed challenging behaviour) to be placed in hospital style settings and many larger residential establishments still exist.

In Serbia, Czech Republic, Italy and Germany, institutional provision is still the main form of provision with little change since previous research (Mansell et al., 2007); in fact, in Italy, numbers of people in larger residential provisions reported now were higher than in 2006/2007 (Mansell et al., 2007). Overall, in all countries larger residential provisions were currently more commonly used for people with ID or mental health problems and less for people with physical or sensory disabilities. The exception to this was Italy where institutional provision for people with ID and mental health problems was challenged earlier than in other countries and where community support was more developed.

Table 1 below also summarises the nature of community-based support available and, where available, the number of people accessing each different type of community-based support. For the most part, this information was only available for people with ID and there was substantial variation between the countries in terms of the numbers or proportions in different settings.

In some countries such as Norway, Sweden, Switzerland, Germany, and the UK, some people with disabilities are supported to live in their own home (on their own or shared with other people), rather than living in a group home or other residential setting in the community. This trend was also emerging as an option in the Czech Republic. However, apart from in the UK, this option is primarily accessed only by those with less severe disabilities. For those with more severe and complex needs, the only option if people are not able to live with their families, is institutional or at least residential care settings. In some countries such as Italy, Germany, Switzerland and Serbia these can be larger hospital-like settings or larger group homes (e.g., for 24 people). In Ireland, options range from small group homes through to larger residential settings and campuses. In others, such as Norway, these are likely to be group homes (identified as small flats co-located with other flats with staff support available up to 24 hours a day).
It is important to note that having a higher proportion of adults living with their families may not denote good community-based support. Variation in the number of people living with their families often reflects religious beliefs and family traditions but it may also reflect a lack of community-based support-in at least some countries the only options were living with family or in an institution. The lower proportion of people living with their family in Norway reflects to some extent the policy to support people with disabilities to be able to move out of the family home and live independently in the community as well as the policy to support parents to have "a life after children".

\subsection{What Choice Do People Have in Relation to Their Living Situation and Other Elements of Their Life?}

Official statistics or research about the number of people who have choice over their living situation was only available for the UK and Ireland and only for people with ID. In Ireland, a survey found that more than half of people with ID had no choice about with whom they lived or where they lived (Inclusive Research Network, 2010). In the UK, similar figures have been reported-almost 50\% of people report no choice in where they live and $1 / 3$ of people reported no choice about with whom they live (Hatton \& Waters, 2013).

In the other countries, it was generally reported that, apart from where people were receiving personal budgets or had a service in the form of personal assistance, choice over where and with whom to live was limited, especially for those with more severe levels of ID. In Norway and Sweden, choice about living situation and support depended very much on the level of service required. In Norway $22 \%$ reported that they had taken part in decisions on where they live, and $15 \%$ on with whom they live (Söderström \& Tøssebro, 2011). Those who needed more intense support were often unable to access a range of choices-being steered towards a group home with only one group home available locally. In the Czech Republic, although in principle people have choice over where they live, in reality this is still currently difficult to achieve (Šiška, 2011).

\subsection{Barriers and Facilitators to Community Living}

For the most part, this section draws on the findings from the interviews with informants. Some of the data used comes from the research teams in each country via the templates mentioned above. Seven clusters of themes related to barriers were identified and for the purpose of this article have been organised into three core areas. These were:

1. Policy and politics;

2. Social care and support systems:

- Funding availability and systems; 
Table 1. Where people with disabilities live in each country and numbers/proportions where available.

$\begin{array}{ll}\text { Living with family } & \text { Small groups homes } \\ (<10 \text { places })-\text { usually }\end{array}$

$(<10$ places $)-$
$24 \mathrm{Hr}$ support

\section{Apartment with \\ support provided \\ by/funded by state,}

etc.-usually less

than 24 hour

support

\begin{tabular}{|c|c|c|c|c|c|c|}
\hline & & & $\begin{array}{l}\text { etc. - usually less } \\
\text { than } 24 \text { hour } \\
\text { support }\end{array}$ & hours) & places) & \\
\hline Norway & $\begin{array}{l}98 \% \text { of children live } \\
\text { with family. No exact } \\
\text { figures available for } \\
\text { adults provided. In } 1999 \\
21 \% \text { of people with ID } \\
\text { over } 21 \text { lived with } \\
\text { their families. }\end{array}$ & $\begin{array}{l}\text { Yes-primarily for } \\
\text { people with ID-average } \\
\text { size } 7 \text { places. }\end{array}$ & $\begin{array}{l}\text { Yes both for people } \\
\text { with ID and some } \\
\text { for people with } \mathrm{MH}\end{array}$ & $\begin{array}{l}\text { Yes }-15 \% \text { of people } \\
\text { with ID are in this type } \\
\text { of setting }\end{array}$ & $\begin{array}{l}\text { Lately some group } \\
\text { homes for more than } \\
10 \text { people are set up } \\
\text { but very few above } 30 \text {. } \\
\text { In the } 1990 \text { s few group } \\
\text { homes were for } \\
\text { more than } 5 \text {. }\end{array}$ & $\begin{array}{l}\text { 150-200 people with } \\
\text { severe physical or } \\
\text { multiple disabilities } \\
\text { live in Health and } \\
\text { Welfare Centres. }\end{array}$ \\
\hline Sweden & Not available. & $\begin{array}{l}\text { Yes-for all client } \\
\text { groups }\end{array}$ & $\begin{array}{l}\text { Not clear from the } \\
\text { data. }\end{array}$ & Yes & $\begin{array}{l}\text { A small number of } \\
\text { people with mental } \\
\text { health needs still live } \\
\text { in groups homes of up } \\
\text { to } 20 \text { people but mostly } \\
\text { these have closed now }\end{array}$ & $\begin{array}{l}\text { None reported in } \\
2006 / 2007 \text { DECLOC } \\
\text { report. No updates in } \\
2016 \text {. }\end{array}$ \\
\hline UK & $\begin{array}{l}\text { No official figures but } \\
\text { various reports have } \\
\text { found that around } 60 \% \\
\text { of adults with ID live } \\
\text { with family. } 2004 \\
\text { Learning Disability } \\
\text { Survey found } 67 \% \text { in } \\
\text { family home. }\end{array}$ & $\begin{array}{l}\text { Yes-this still remains } \\
\text { the most common form } \\
\text { of accommodation and } \\
\text { support service in the } \\
\text { UK }\end{array}$ & $\begin{array}{l}\text { Yes-exists usually } \\
\text { for people with } \\
\text { challenging } \\
\text { behaviour }\end{array}$ & $\begin{array}{l}\text { Yes-this is increasing. } \\
\text { In } 2010 / 201142,625 \\
\text { people with ID were using } \\
\text { self-directed support or } \\
\text { direct payments }-81 \% \\
\text { more than } 2009 / 2010 \text {. } \\
\text { However, the biggest } \\
\text { increase was for council } \\
\text { services only-i.e., where } \\
\text { the individual allocation is } \\
\text { still used to pay for } \\
\text { social care services that } \\
\text { are traditional and } \\
\text { not really new models }\end{array}$ & $\begin{array}{l}\text { Yes-there are } \\
\text { some larger } \\
\text { residential services } \\
\text { based in the } \\
\text { community that } \\
\text { provide for } \\
\text { between } 10 \text { and } 30 \\
\text { people (usually less } \\
\text { than 20). Primarily } \\
\text { for people with ID } \\
\text { but also with } \\
\text { physical and } \\
\text { sensory disabilities. }\end{array}$ & $\begin{array}{l}66,342 \text { was the estimate } \\
\text { given in } 2006 / 2007 \\
\text { DECLOC report. No } \\
\text { updated official statistics } \\
\text { in } 2016 \text { but likely to be } \\
\text { less due to the closure } \\
\text { of remaining long stay } \\
\text { hospitals, NHS campuses } \\
\text { and the ongoing closure } \\
\text { of assessment and } \\
\text { treatment units, and } \\
\text { private hospitals for } \\
\text { people with IDD. } \\
\text { Approximately } 2500 \\
\text { people with IDD are still } \\
\text { in inpatient services } \\
\text { which range in size. }\end{array}$ \\
\hline
\end{tabular}

\section{Own home \\ Larger residential \\ Institution (30}

(rented/owned) with

assistance (up to 24

hours)

places) home (10 or more

but less than 30 
Table 1. Where people with disabilities live in each country and numbers/proportions where available. (Cont.)

\begin{tabular}{|c|c|c|c|c|c|c|}
\hline & Living with family & $\begin{array}{l}\text { Small groups homes } \\
\text { ( }<10 \text { places })- \text { usually } \\
24 \mathrm{Hr} \text { support }\end{array}$ & $\begin{array}{l}\text { Apartment with } \\
\text { support provided } \\
\text { by/funded by state, } \\
\text { etc.-usually less } \\
\text { than } 24 \text { hour } \\
\text { support }\end{array}$ & $\begin{array}{l}\text { Own home } \\
\text { (rented/owned) with } \\
\text { assistance (up to } 24 \\
\text { hours) }\end{array}$ & $\begin{array}{l}\text { Larger residential } \\
\text { home ( } 10 \text { or more } \\
\text { but less than } 30 \\
\text { places) }\end{array}$ & $\begin{array}{l}\text { Institution (30 } \\
\text { places or more) }\end{array}$ \\
\hline Czech Republic & Numbers not available & $\begin{array}{l}\text { Yes-usually } 6 \text { to } 10 \\
\text { places-all disability } \\
\text { groups but not mixed. }\end{array}$ & $\begin{array}{l}\text { Yes-some } \\
\text { institutions rent flats } \\
\text { for those who don't } \\
\text { need so much } \\
\text { support to live in- } \\
\text { usually as a group } \\
\text { though. }\end{array}$ & $\begin{array}{l}\text { Is possible with social } \\
\text { assistance funding. } \\
\text { Tendency growing but no } \\
\text { exact numbers available. }\end{array}$ & & $\begin{array}{l}30987 \text { were recorded } \\
\text { in the } 2006 / 2007 \\
\text { DECLOC report. No } \\
\text { updated data in } 2016 \text {. }\end{array}$ \\
\hline Serbia & $\begin{array}{l}563000 \text { live with } \\
\text { families }-98 \% \text { of } \\
\text { those with a disability. }\end{array}$ & $\begin{array}{l}441 \text { adults and } 661 \\
\text { children (size not } \\
\text { indicated) }\end{array}$ & & 196 adults & & $\begin{array}{l}\text { Very little information } \\
\text { but approximately } \\
8000 \text { people thought } \\
\text { to be in institution, } \\
\text { primarily accounted } \\
\text { for by people with } \\
\text { psychosocial } \\
\text { disabilities ( } 47 \%) \text { and } \\
\text { people with ID (32\%). }\end{array}$ \\
\hline Ireland & $\begin{array}{l}85.5 \% \text { of people with } \\
\text { physical and sensory } \\
\text { disabilities and } 66.4 \% \\
\text { of people with ID live } \\
\text { with family members }\end{array}$ & $\begin{array}{l}4226 \text { people with ID. } \\
\text { Also used by a small } \\
\text { number of people with } \\
\text { physical disabilities }\end{array}$ & & & $\begin{array}{l}2561 \text { people with ID. } \\
343 \text { people with } \\
\text { physical and sensory } \\
\text { disabilities. } \\
52 \text { people with } \\
\text { psychosocial } \\
\text { disabilities. }\end{array}$ & $\begin{array}{l}5123 \text { had been reported } \\
\text { in } 2006 / 2007 \text { DECLOC } \\
\text { report. Approximately } \\
4000 \text { people reported } \\
\text { for } 2016 \text {. Mainly ID but } \\
\text { also some psychosocial } \\
\text { disabilities and sensory } \\
\text { disabilities. }\end{array}$ \\
\hline
\end{tabular}


Table 1. Where people with disabilities live in each country and numbers/proportions where available. (Cont.)

\begin{tabular}{|c|c|c|c|c|c|c|}
\hline & Living with family & $\begin{array}{l}\text { Small groups homes } \\
\text { ( }<10 \text { places })- \text { usually } \\
24 \mathrm{Hr} \text { support }\end{array}$ & $\begin{array}{l}\text { Apartment with } \\
\text { support provided } \\
\text { by/funded by state, } \\
\text { etc.-usually less } \\
\text { than } 24 \text { hour } \\
\text { support }\end{array}$ & $\begin{array}{l}\text { Own home } \\
\text { (rented/owned) with } \\
\text { assistance (up to } 24 \\
\text { hours) }\end{array}$ & $\begin{array}{l}\text { Larger residential } \\
\text { home ( } 10 \text { or more } \\
\text { but less than } 30 \\
\text { places) }\end{array}$ & $\begin{array}{l}\text { Institution (30 } \\
\text { places or more) }\end{array}$ \\
\hline Germany & $\begin{array}{l}\text { No recent figures } \\
\text { available-in 1990s } \\
\text { had been estimated at } \\
\text { approximately half of } \\
\text { people with } \\
\text { disabilities. }\end{array}$ & $\begin{array}{l}\text { No recent figures but } \\
\text { DECLOC report } \\
\text { identified that this type } \\
\text { of service exists, } \\
\text { although in the minority. }\end{array}$ & $\begin{array}{l}\text { No recent figures but } \\
\text { DECLOC report } \\
\text { identified that this } \\
\text { type of service exists, } \\
\text { although in the minority. }\end{array}$ & $\begin{array}{l}\text { No recent figures but } \\
\text { DECLOC report } \\
\text { identified that this type } \\
\text { of service exists, } \\
\text { although in the minority. }\end{array}$ & $\begin{array}{l}\text { No recent figures } \\
\text { but DECLOC } \\
\text { report identified } \\
\text { that this type of } \\
\text { service exists- } \\
\text { most common type } \\
\text { of community-based } \\
\text { support. }\end{array}$ & $\begin{array}{l}\text { 190,146 estimated in } \\
\text { 2006/2007 DECLOC } \\
\text { report. } \\
\text { Updated to 202,359 } \\
\text { in 2016. } 64 \% \text { are } \\
\text { people with ID; } 26 \% \\
\text { psychosocial } \\
\text { disabilities. }\end{array}$ \\
\hline Switzerland & $\begin{array}{l}\text { No data available for } \\
\text { living with family- } \\
\text { only private } \\
\text { households which are } \\
\text { not necessarily family } \\
\text { homes-could be } \\
\text { person in their own } \\
\text { home. }\end{array}$ & \multicolumn{4}{|c|}{$\begin{array}{l}\text { 1,134,000 persons with disabilities ( } 94 \% \text { ) lived in private households in } 2010 \text { : } \\
\text { physical disability }-76.4 \% \text {, ID } 6.8 \% \\
\text { both } 15.8 \% \text {, neither physical nor intellectual } 1.0 \% \\
\text { Personal assistance payments: persons with disabilities who are unable to take care of themselves are entitled } \\
\text { to receive extra disability benefits to pay for the extra costs that arise due to these limitations. The percentage } \\
\text { of persons who receive such benefits and who live at home has risen from } 50 \% \text { in } 2004 \text { to } 59 \% \text { in } 2011 . \\
\text { There were more than } 25000 \text { people living in some form of service provision (referred to as institutions } \\
\text { but no information available on size): } \\
\text { physical disability } 11.0 \% \text {, psychosocial disability } 20.1 \% \\
\text { ID } 55.4 \% \text {, sensory disability } 2.7 \% \text {, others (addiction, etc.) } 10.7 \%\end{array}$} & $\begin{array}{l}\text { No data available o } \\
\text { size of setting. } 25000 \\
\text { people living in some } \\
\text { type of service. } 55 \% \\
\text { were people with ID, } \\
20 \% \text { psychosocial } \\
\text { and } 11 \% \text { physical } \\
\text { disabilities. }\end{array}$ \\
\hline Italy & $\begin{array}{l}\text { Majority live with their } \\
\text { family-main support } \\
\text { for } 83 \% \text { of people with } \\
\text { disabilities is their } \\
\text { family. }\end{array}$ & $\begin{array}{l}\text { Smaller family houses } \\
\text { from } 7 \text { to } 9 \text { places }\end{array}$ & $\begin{array}{l}\text { Supported } \\
\text { apartments-from } 1 \\
\text { to } 4 \text { people who } \\
\text { have chosen to live } \\
\text { with other people. } \\
\text { Only for people with } \\
\text { physical and sensory } \\
\text { disabilities with low } \\
\text { support needs. }\end{array}$ & & $\begin{array}{l}\text { Smaller Sanatorium } \\
\text { Residences-RSA } \\
\text {-from } 12 \text { to } 120 \\
\text { people. } 2 \text { or more } \\
\text { people frequently } \\
\text { share a room. } \\
\text { Larger family } \\
\text { Houses-from } 10 \\
\text { disability groups were }\end{array}$ & $\begin{array}{l}153,798 \text { had been } \\
\text { estimated in } \\
2006 / 2007 \text { DECLOC } \\
\text { report. } \\
\text { In } 2016 \text { this was } \\
190,134 \text {. } \\
\text { People from all } \\
-20 \text { places } \\
\text { in institutions. }\end{array}$ \\
\hline
\end{tabular}


- Co-ordination and organisation across levels of government and other agencies;

- Availability and flexibility of services and support in the community;

- Perverse incentives for the maintenance of institutional provision, contractions in the system and issues of definition and conceptualisation.

3. Attitudes, awareness and advocacy:

- Attitudes and awareness;

- Influence of people with disabilities and their representatives.

\subsubsection{Policy and Politics}

Although all countries studied were reported to have at least some national policies and/or legislation in support of the social inclusion, self-determination and deinstitutionalisation of people with disabilities, expert informants reported substantial variation in the extent and usefulness of existing policy (see Figure 1 ). In some countries, policy was very limited or the policy that existed was perceived to have the wrong focus or was not helpful in promoting community living. For example, informant identified weak policy on accessibility in Sweden; policy in Norway being open to interpretation and medical model still prevalent in Ireland. In addition, guardianships laws were seen to impact on whether people have real choice and control. Even where good policy existed, it was reported that there were issues of full implementation in Serbia, Czech Republic, Italy and Ireland.

A lack of government focus or priority on disability issues was also identified as a barrier in the Czech Republic, Norway, Italy and Germany. In addition, in Norway, the almost exclusive focus on promoting personal budgets to the exclusion of all other options for services was viewed as problematic especially for those with more complex needs.

Other political factors included the lack of political stability in Italy, the controlling nature of government in Italy and Serbia, the way the government responded to crises in the UK and factors related to government focus on costs, expenditure and rationing of services in Germany, Ireland, UK and Sweden.

\subsubsection{Social Care and Support Systems}

In all countries except Norway and Sweden, interviewees identified the issue of a lack of spending on disability as a key barrier. In some cases, this was due to a general reduction in spending over time. In others, it was due to austerity measures as a result of the financial crisis (see Figure 2). The lack of funding applied both directly in terms of funding for support and housing and also in terms of funding for schemes that would help people be more independent and therefore reduce reliance on formal services. Examples included lack of funding for families to prevent institutionalisation or lack of eligibil-

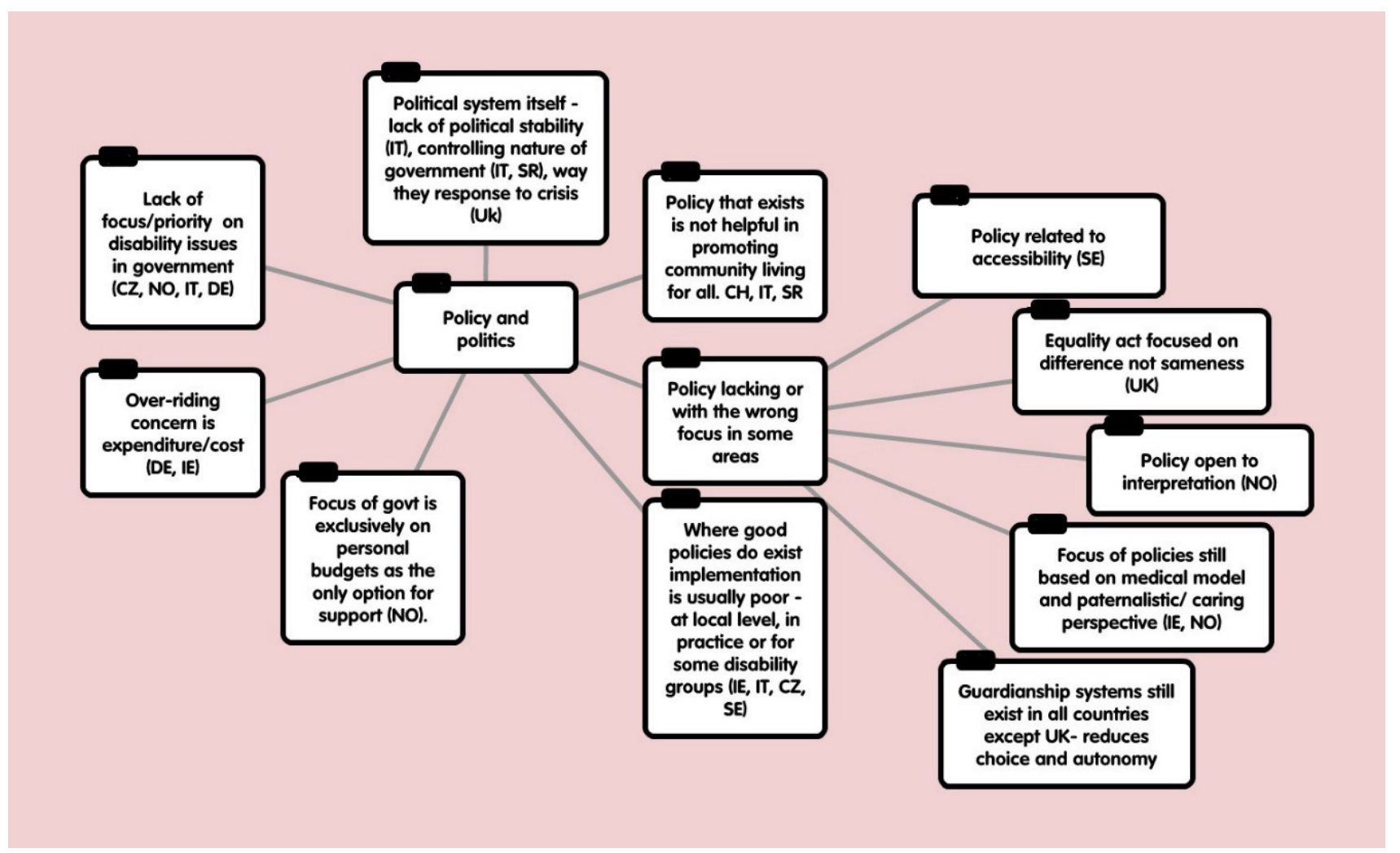

Figure 1. Themes identified in the cluster related to policy and politics. 
ity for funding for services such as self-help groups for those with psychosocial disabilities. Inefficiency in spending, spending on the wrong types of support, misuse of structural funds and lack of leadership related to spending were also identified as issues, especially in Italy.

There were three core barriers identified that affected co-ordination and consistency within the system (see Figure 3). Geographical fragmentation was a factor in most countries, for example, regional variation was reported between Länder in Germany, cantons in Switzerland and local authorities in the UK. In six of the nine countries, interviewees identified a lack of co-ordination between different levels of government as a barrier to widespread change happening more consistently and sometimes this was identified as a way of cost shunting from one department or level of government to another. Finally, interviewees in Sweden, Ireland and Germany identified compartmentalisation of the system as a barrier along with lack of co-ordination and co-operation between service providers, agencies and across sectors (e.g., health, social care, education, transport, etc.).

\subsubsection{Availability and Flexibility of Services and Support in the Community}

This was one of the bigger clusters, with nine themes (see Figure 1). The only country not represented within this cluster was Serbia where this was not raised as an issue-possibly because services in the community were relatively rare as this quote from one of the informants from Serbia illustrates: 'Everything is still a matter of who knows who, and of individual efforts. There is no systemic support or conditions'.

Firstly, in Switzerland, Germany and Italy, the issue of the bureaucracy involved in obtaining and then managing a personal budget or personal assistance made it difficult and off-putting for many people with disabilities. The fact that people had to be employers for personal assistants was a particular issue raised. There was also discrimination against people with ID and psychosocial disabilities. In Italy, assistance was only given for personal and health care and not for social assistance which made it less useful for those with more severe disabilities:

Another problem is the discrimination of people with psychosocial problems and with cognitive impairments since the eligibility for the assistance budget depends on the eligibility for the so-called Hilflosenentschädigung ("compensation for the helpless"), for which restrictions exist for people with psychosocial problems and cognitive impairments.... Only few people are able to overcome the barriers on the way to receiving the assistance budget. $(\mathrm{CH})$

Secondly, in Switzerland, Czech Republic, Italy and Germany, institutional services were still being built or at the very least still being used for new people entering the service system. In the Czech Republic, the continued use

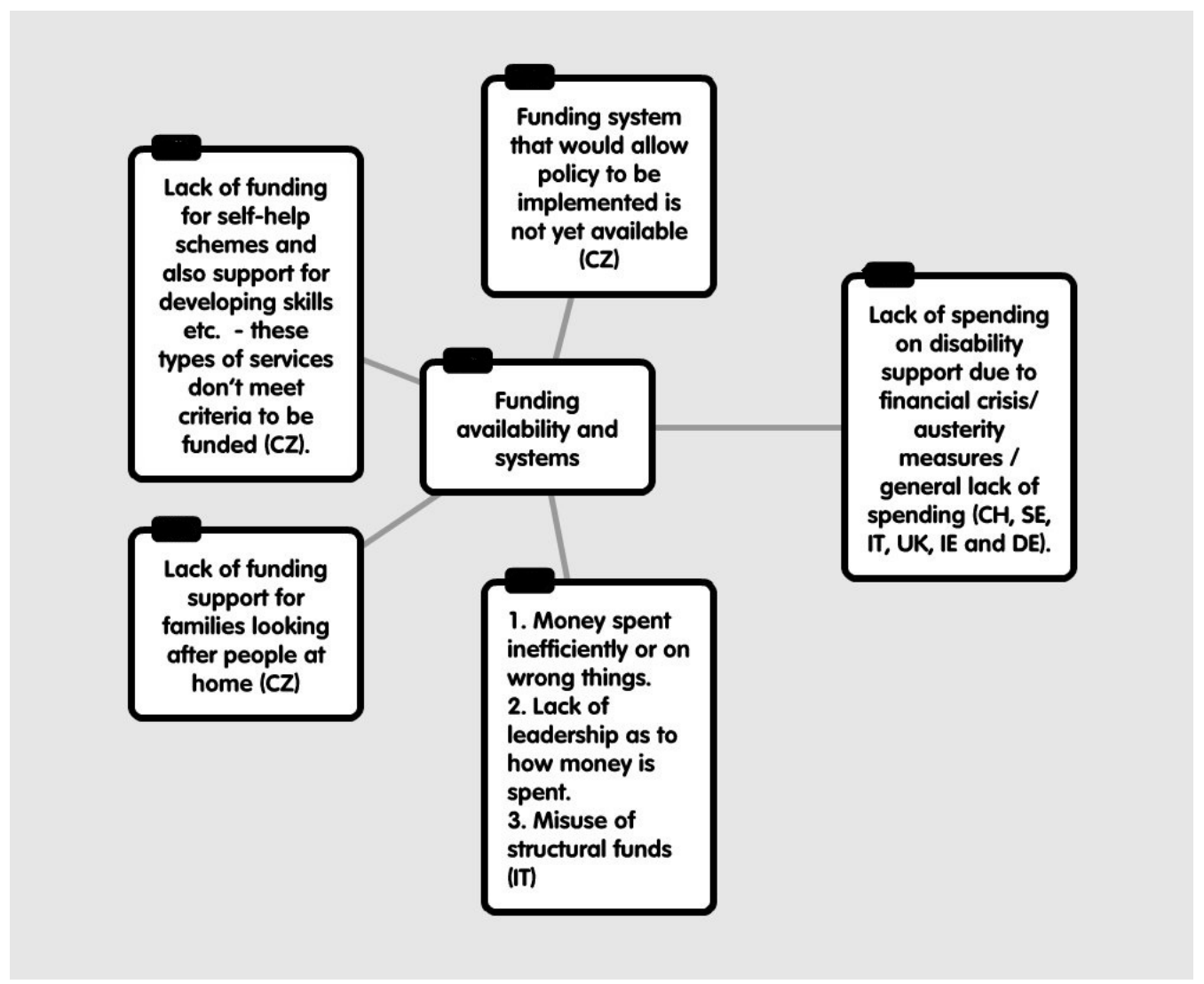

Figure 2. Themes related to the cluster of funding availability and funding systems. 

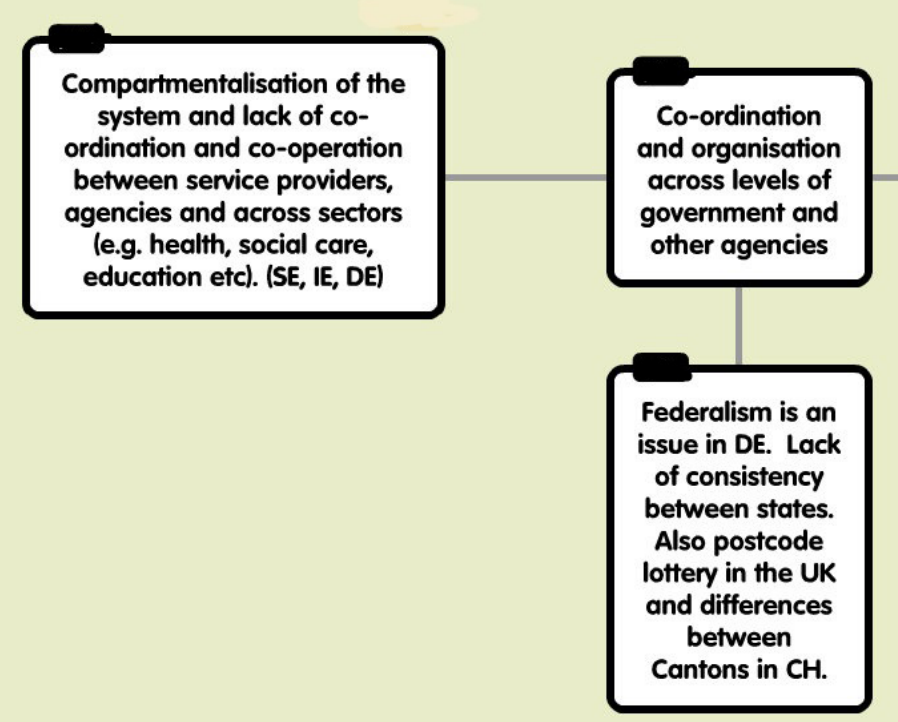

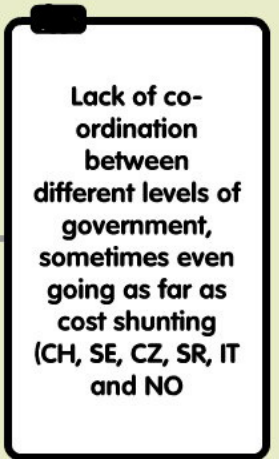

Lack of coordination between ifferent levels of government going as far as cost shunting , SE, CZ, SR, IT and NO

Figure 3. Themes identified within the cluster of co-ordination and organisation across levels of government and other agencies.

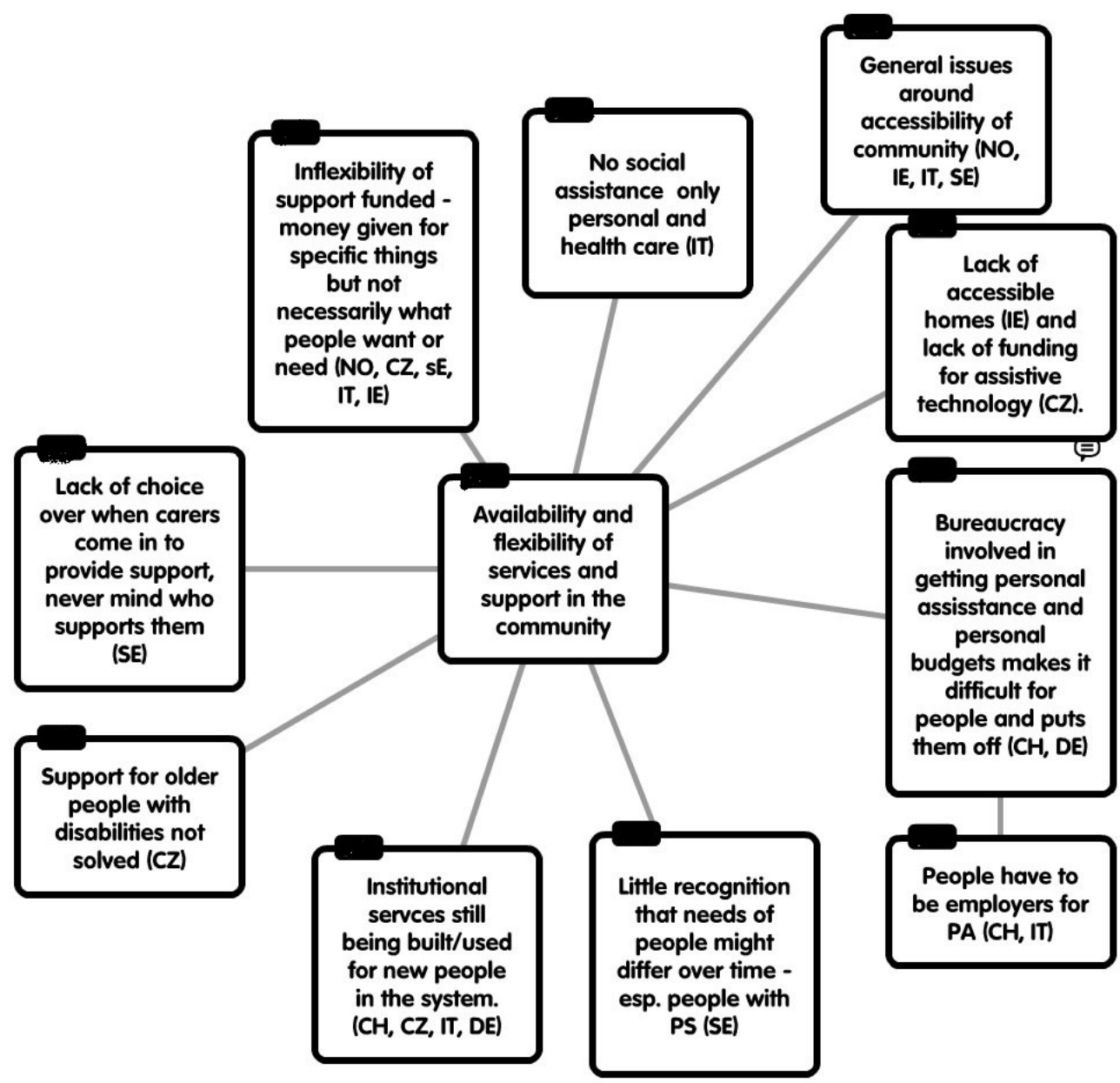

Figure 4. Themes identified within the cluster of availability and flexibility of services and support in the community (PA = personal assistant, PS = psychosocial disabilities). 
of institution was compounded by uncertainly in how to support older people with disabilities and gave rise to the belief that institutions were still needed.

Inflexibility of funded support was raised as an issue in six of the nine countries (NO, CZ, SE, IT and IE) with money sometimes given but not necessarily for the support desired or needed. For those with mental health conditions, this inflexibility was reflected in the lack of recognition that the needs of people might differ over time and as such support might need to vary over time. Inflexibility was also reflected in the lack of choice over who provides support and when support is provided.

Finally, there were barriers identified around the accessibility of community in general (Norway, Ireland, Italy and Sweden), accessible homes (Ireland) and the availability of assistive technology in the Czech Republic.

\subsubsection{Perverse Incentives for the Maintenance of} Institutional Provision, Contradictions in the System and Issues of Definition and Conceptualisation

Figure 5 illustrates that there were still financial incentives for institutional services in some countries. For example, in Germany and Switzerland it was identified that local levels of government were motivated to keep institutions open as this is cheaper for them than community- based services. The per capita basis for funding psychiatric care in Ireland meant that so there was no incentive to close the institutions.

In Germany, one informant reported that First Civil Society Report on UN CRPD 2013 highlighted that the word the word integration is purposely rather than the word inclusion (Alliance of German Non-Governmental Organizations regarding the UN Convention on the Rights of Persons with Disabilities, 2013).

Finally, there was an issue about inherent attitudes or ways of working within the systems, for example in many countries, the systems still fostered dependency rather than independence. This is related to the deeprooted attitude in society that disability = charity required, which was felt to be related to the increase (Italy) or at least maintenance (Germany) of special/segregated educational provision. Individual resources and contact and being able to speak up for yourself were felt to determine the services received.

\subsubsection{Awareness, Attitudes and Advocacy}

Figure 6 illustrates the themes focused on awareness of issues faced and attitudes towards people with disabilities, with many emerging themes interlinked. It was noted that society was more individualistic and less

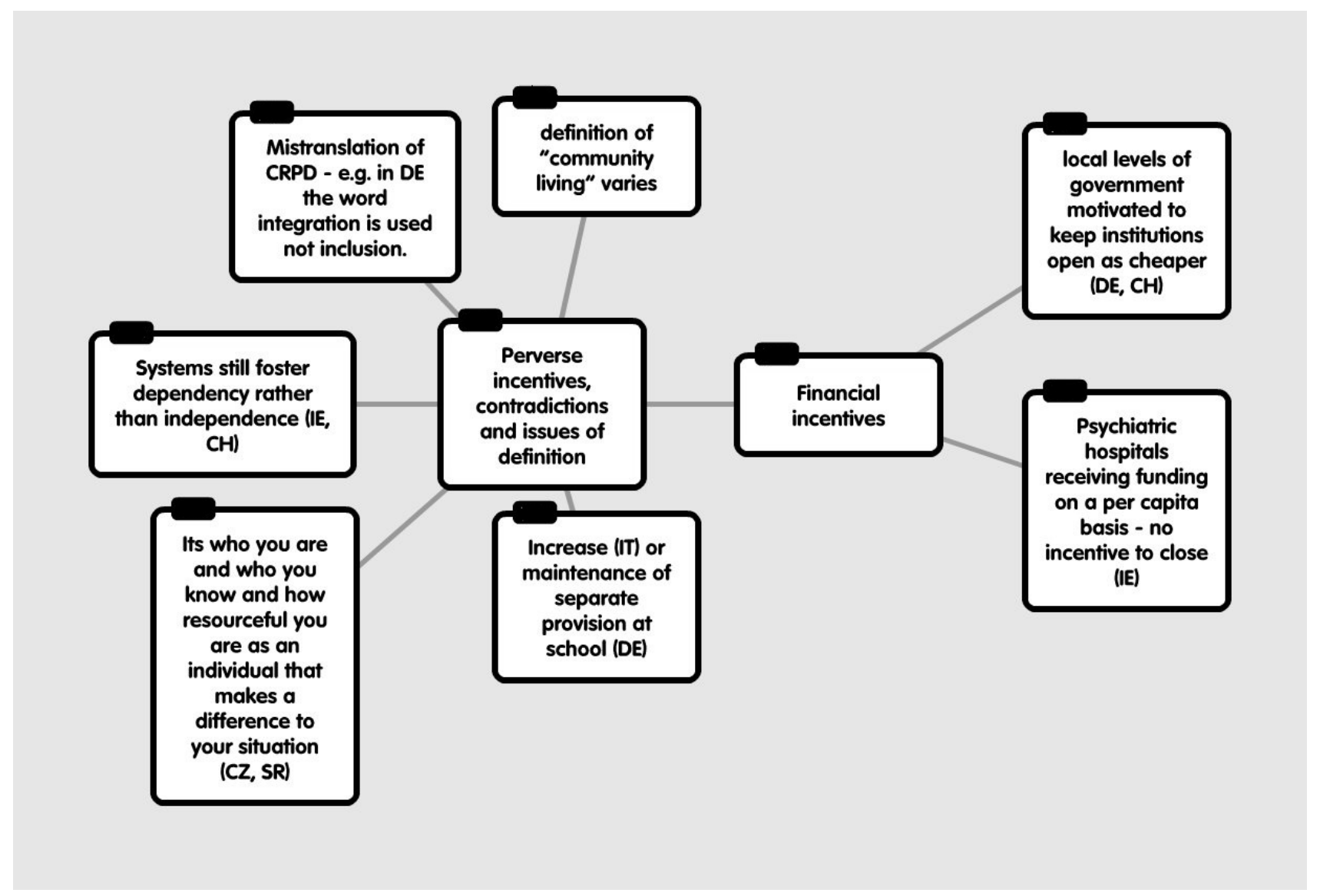

Figure 5. Themes within the cluster on perverse incentives for the maintenance of institutional provision, contradictions in the system and issues of definition and conceptualisation. 


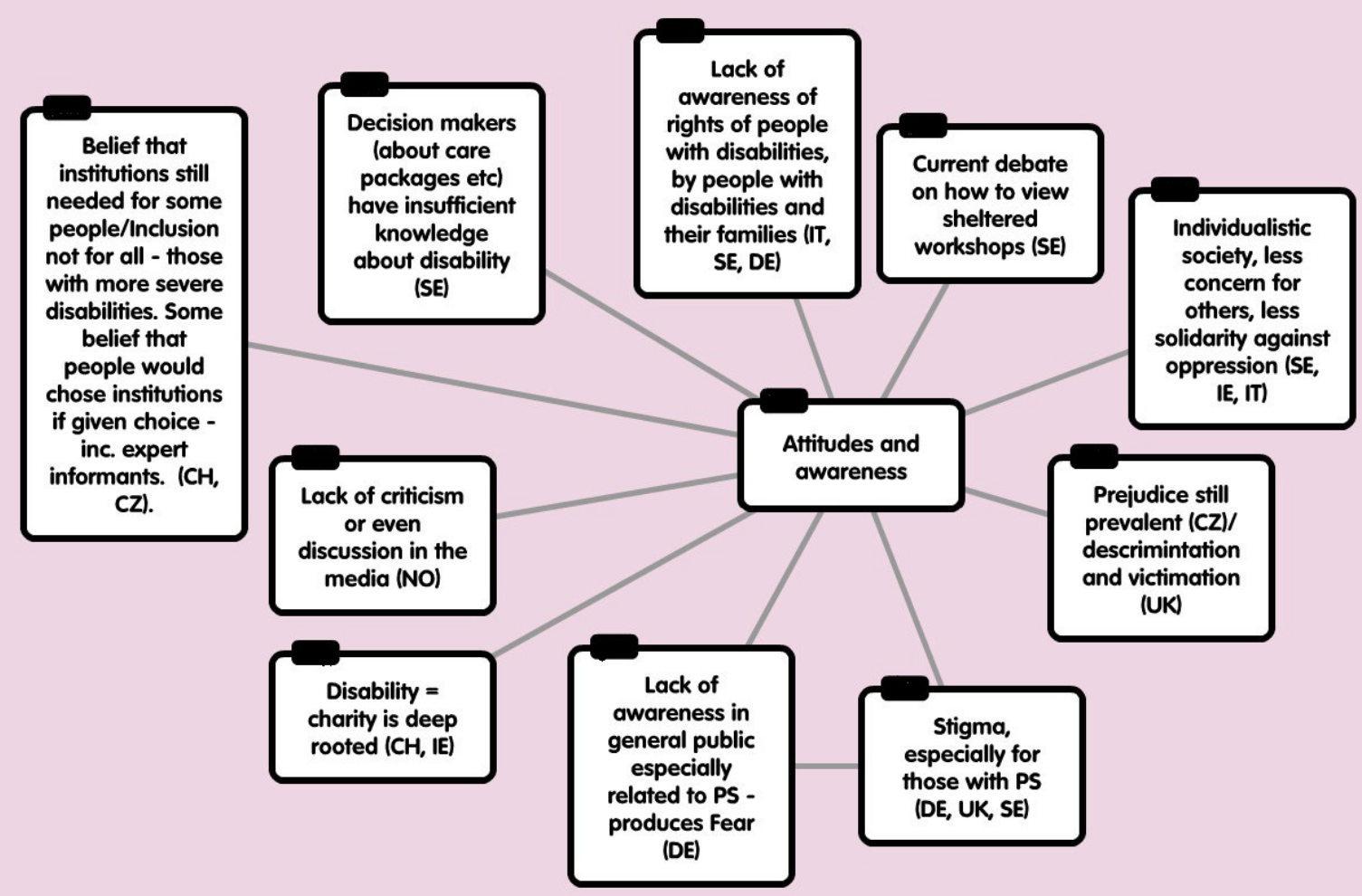

Figure 6. Themes identified within the cluster on attitudes and awareness (PS = psychosocial disability).

concerned about others or at least with less solidarity against oppression than in the past. Prejudice, discrimination, victimisation and stigma were raised as issue, in particular in the Czech Republic, Germany and Sweden, especially with regard to people with mental health conditions, with a lack of awareness around mental health conditions being identified in Germany.

Lack of knowledge and awareness on the part of decision makers (i.e., those deciding on care packages) was raised as a barrier in Sweden, as was a lack of awareness of the rights of people with disabilities by people with disabilities themselves and their families. The latter was also seen as a barrier to change in Italy and Germany.

As mentioned above, there was still a belief that institutions were needed, in particular in Czech Republic and Switzerland, although this was at times somewhat confused by differing definitions of an institution. This belief extended to the fact that people would choose to live in institutions and that having institutions was necessary to give people a full range of choices. These attitudes also applied to some of the interviewees, which was concerning given their leading role in advocating for or delivering community living. Another barrier related to the deeprooted belief-in Ireland and Switzerland in particularthat disability equated to charity and that the primary aim of services and support mechanisms, was to care for, rather than empower and enable, people.

The lack of criticism or even discussion related to disability issues in the media was raised as an issue in Nor- way. Unlike in other countries such as the UK, where scandals were common and much debated, in Norway there appeared little discussion about the situation of people with disabilities.

The final cluster of themes revolved around the influence of people with disabilities. For all countries, the lack of involvement of people with disabilities (both directly and through disabled people's organisations) in the political arena emerged as an issue. In the UK, Serbia and Ireland, it was identified that influence was limited to the "elite"-i.e., powerful, well-resourced and well-known individuals. In Switzerland, it was noted that politicians do not acknowledge the need to involved people with disabilities - they do not necessarily subscribe to the "nothing about us without us" maxim. Finally, in Norway, Italy and Sweden, the fragmentation of disabled people's organisations was identified as an issue-they were not working together to put forward a united front and as such were not strong enough to influence government and local decision makers.

\subsection{Facilitators of Community Living}

As one might imagine, the facilitators identified by informants in each country were in general the opposite of the barriers already outlined above. Figure 7 below presents the key facilitators that were identified by the informants as having been important in bringing about change in favour of community living. 


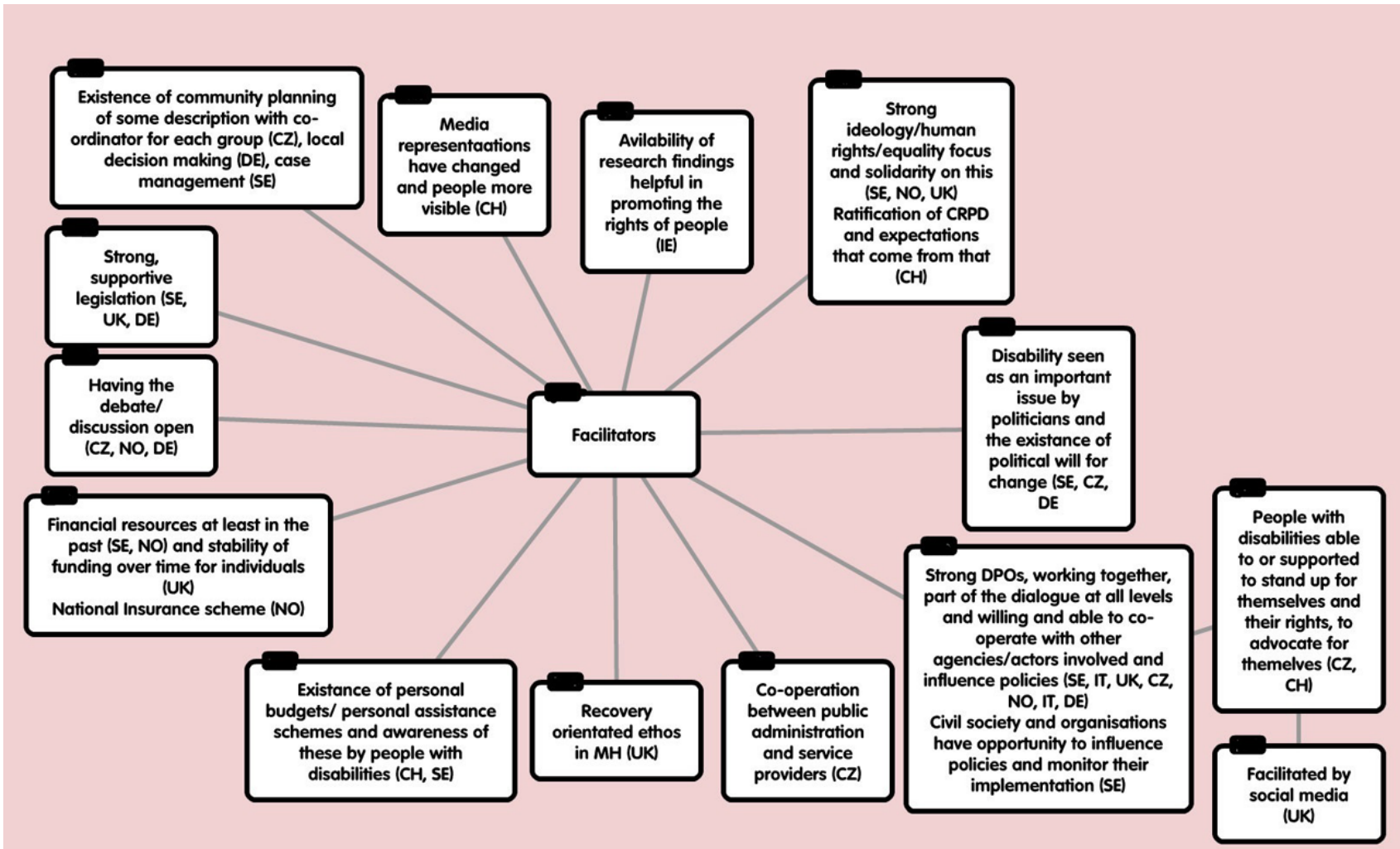

Figure 7. Themes arising under the topic of facilitating factors for community living.

The facilitators that were seen as most important for future success included good co-ordination between different levels of government and between different agencies and services-allowing a more holistic and comprehensive approach to ensure people's needs are met. Also, important for future changes was the involvement of people with disabilities in decision- and policy-making and collaboration of disabled people's organisations for a stronger, united voice.

\section{Conclusions}

This article aimed to provide an overview of the current situation for people with disabilities, in terms of community living as defined in the UN CRPD Article 19. Living and actively participating in your local community, with equal opportunities and choices to those experienced by those without disabilities, is a critical first step to full social inclusion and active citizenship. Although there appeared to have been some advances in the development of policy and funding systems in some countries to allow, for example, personal budgets and personal assistance, there has been little change in the numbers of people with disabilities living in larger congregate settings and little evidence of strong development of community-based services to prevent institutionalisation. In some countries, families are still the primary or indeed only form of community living but with little to no support. Only in the Nordic countries was there a policy and associated practices to ensure that adults with disabilities could live independently from their parents.

However, as for previous studies, getting an accurate and detailed picture of the living situation of people with disabilities was hampered by a lack of reliable data in almost all countries. Mansell et al. (2007) concluded that none of the 28 countries in the DECLOC study were yet in compliance with Article 31-ten years on, this appears to still be the case. For some of the countries in this study, the data collected in 2006/2007 as part of the DECLOC study was the most recent data available on the living situation of people with disabilities. Only in Ireland was there any type of register that provided data on living situation and support-although this was only for people with ID and those with physical and sensory disabilities who were known to services and did not include those that were living at home on their own or with family without support. Even when information was available on the number of people receiving a service, the size and/or nature of those services were not always available. In other cases, the data is only on the number of places in a setting, not how many people are actually living there. The lack of complete, or at least reliable and accurate, data is in itself a barrier to the developing of a strong system of community-based support as it makes it difficult to check whether nations are "progressively realising" even Article 19 of the UN CRPD and thus limits accountability for the process. 
Secondly, a true understanding of whether people with disabilities are really experiencing community living on an equal basis with others is hampered by variations in definitions used-e.g., what is an institution in one country may not be classed as an institution in another country. The only type of service/support about which there was more certainty was personal budgets and personal assistance, where in general, people receiving this type of support were living in their own home in the community. However, no official data, and almost no research, existed on the quality of those supports, on whether people had choice about their living situation and support, or whether the support they received supported their inclusion in the community more generally. There was also no research found that allowed comment on whether those with disabilities had access to the same range of housing options as the rest of the population and whether they had access to communitybased facilities on an equal basis with others.

Compiling statistical data from many different sources and of varying quality can result in methodological weakness and limit the conclusions that can be drawn. Whilst having reliable and consistent data to compare across countries would be methodologically preferable, in reality such comparable data does not currently exist. As such, it was considered essential to use the data that were available, recognising the limitations.

With regards to issues related to drawing on the views of a relatively small number of informants in each country, it is recognised that the views and experiences reported may not be either universal or representative. However, there is still validity in gathering these experiences-if those responsible or active in helping people live and participate in the community have experienced such issues in their work, it is highly likely that other people will also have experienced them.

Despite these limitations, it was clear that people were still living in institutional settings in almost every country. In some countries, this was still the main form of provision, whilst in others small improvements had been observed. Although there were important differences between different regions, it was the variation between different groups of people with disabilities that was most striking. Evidence of inequality between different disability groups was apparent in the findings. Community living was more thoroughly developed for those with mobility difficulties and those with visual impairments and was least developed for those with ID, especially those with the most severe or complex needs. For this group of people, the only option in most cases where people are not able to live with their families remains institutional or residential care settings. Only in the UK were those with severe ID reported to regularly access personal budgets and personal assistance. Apart from in Italy, where mental health services were reformed first, people with psychosocial disabilities were considered to receive the poorest support, with the lack of flexibility in support raised as a key issue.
In terms of barriers to and facilitators of community living, cuts in public spending and changes in public governance were amongst the explanatory factors identified. Supportive policy and funding systems were both seen as important but sometimes either didn't go far enough, were still based on a medical model, still included incentives for institutions, and were easily misinterpreted or simply not flexible enough to meet the needs of individuals. The need to involve people with disabilities in policymaking and the need for a co-ordinated approach between all actors in the disability sector was seen as critical for achieving further change. A more holistic approach to services and support was identified as needed for success.

Awareness and attitudes in general were also identified as a barrier with some indication that the views and actions of other members of the community can also be a barrier to active participation although research on this is limited.

The availability of personal budgets, direct payments or other individualised funding systems were reported as a core facilitator of community living. However, where personal budgets existed they were often made very complex to access, only available to some people, limited by a lack of available services for people to purchase and were sometimes seen by governments as a way of saving money. Where people did get involved in their community, this was often seen as down to personal will and the level and quality of support someone gets, which was not always formal support.

This article drew on official information, previous research in each country and the views of those who were seen to have some expertise on the situation for people with disabilities in their countries. Although some of these were people with disabilities themselves, many were not. However, findings from interviews with over 200 people with disabilities, across the nine countries and born between 1945 and 1995, identified many of the same issues, barriers and facilitators. The difference between the people with disabilities and the informants was that those with disabilities focused more on the barriers to how they could exercise their active citizenship personally rather than at a systems level (Šiška, Beadle-Brown, Káňová, \& Kittelsaa, 2017). Negative attitudes, low awareness and low expectations were also see as a key barrier by those with disabilities as well as the availability and flexibility of support services. People reported that sometimes the support they received was just what was available not what they needed and often they had little choice over who supported them and when support was provided. Those who had a personal budget fared slightly better but even then, receiving the support they needed to be active in the local community was not guaranteed. Lack of training for staff was also identified as an issue and discrimination and issues of accessibility were key barriers to gaining employment and taking part in leisure and cultural activities. 
When it came to facilitators of community living and active citizenship, those with disabilities did talk about some more systemic issues such as greater accessibility and investment in services. One participant finished his interview with a call for politics to "engage more, care more and do more" (Šiška et al., 2017, p. 59).

In conclusion, there continues to be a lack of data available that allows definitive comment on whether the countries involved in this study are really moving towards successful implementation of the UN CRPD. However, from what information is available, it appears that not only do people with disabilities still face inequality in comparison to people without disabilities but there is still a lack of equality between disability groups with more advancements towards community living and participation, on an equal basis with others, for those with mobility and sensory disabilities than those with intellectual or psychosocial disabilities.

\section{Acknowledgements}

The authors wish to thank all our colleagues in the DISCIT consortium, in particular those who collected and collated the data in each country. More information on the DISCIT project and the Consortium can be found at https://blogg.hioa.no/discit. We also thank all the informants who gave up their time to be interviewed.

\section{Conflict of Interests}

The authors declare no conflict of interests.

\section{References}

Alliance of German Non-Governmental Organizations regarding the UN Convention on the Rights of Persons with Disabilities. (2013). First civil society report on the implementation of the UN convention on the rights of persons with disabilities in Germany.

Allard, M. A. (1996). Supported living policies and programmes in the USA. In J. Mansell \& K. Ericsson (Eds.), Deinstitutionalization and community living: Intellectual disability services in Britain, Scandinavia and the USA (pp. 97-116). London: Chapman and Hall.

Committee on the Rights of Persons with Disabilities. (2017). General comment No. 5 (2017) on living independently and being included in the community (CRPD/C/GC/5). Retrieved from http://www. ohchr.org/EN/HRBodies/CRPD/Pages/GC.aspx

Deacon, B. (1993). Developments in East European social policy. In C. Jones (Ed.), New perspectives on the welfare state in Europe. London: Routledge.

DISCIT. (2013). WP2: Active citizenship for Europeans with disabilities-Current knowledge and analytical framework. Retrieved from https://blogg.hioa.no/ discit/files/2016/02/DISCIT-D2_1-Active-Citizenshipfor-persons-with-disabilities_October-2013.pdf

Esping-Andersen, G. (1990). The three worlds of welfare capitalism. Cambridge: Polity Press.

Hatton, C., \& Waters, J. (2013). National personal budgets survey 2013: Summary of main findings and next steps. Lancaster: Lancaster University and In Control.

Inclusive Research Network. (2010). Where we live: A national study done by members of the Inclusive Research Network through surveys. Inclusive Research Network.

King's Fund. (1980). An ordinary life: Comprehensive locally-based residential services for mentally handicapped people. London: King's Fund.

Kinsella, P. (1993). Supported living: A new paradigm. Manchester: National Development Team.

Mansell, J., \& Beadle-Brown, J. (2012). Active support: Enabling and empowering people with intellectual disabilities. London: Jessica Kingsley Publishers.

Mansell, J., Knapp, M., Beadle-Brown, J., \& Beecham, J. (2007). Deinstitutionalisation and community livingOutcomes and costs (Report of a European study, Volume 2: Main report). Canterbury: Tizard Centre, University of Kent.

Miller, F. A., \& Katz, J. H. (2002). The inclusion breakthrough: Unleashing the real power of diversity. San Francisco, CA: Berrett-Koehler.

O’Brien, J. (1987). A guide to life-style planning. In G. T. Bellamy \& B. Wilcox (Eds.), A comprehensive guide to the activities catalog: An alternative curriculum for youths and adults with severe disabilities ( $\mathrm{pp}$. 175-189). Baltimore: Paul H. Brookes.

Rosenthal, E., \& Kanter, A. (2002). The right to community integration for people with disabilities under United States and international law. In Principles to practice; Disability rights law and policy international and national perspectives (pp. 309-368). Ardsley, NY: Transnational Publishers.

Schalock, R. L., Brown, I., Brown, R., Cummins, R. A., Felce, D., Matikka, L., \& Parmenter, T. (2002). Conceptualization, measurement, and application of quality of life for persons with intellectual disabilities: Report of an International Panel of Experts. Mental Retardation, 40(6), 457-470.

Šiška, J. (2011). ANED, country report on the implementation of policies supporting independent living for disabled people, Czech Republic. Retrieved from http:// www.disability-europe.net/downloads/333-cz-8-re quest-07-aned-2009-task-5-request-template-to-pub lish-to-ec

Šiška, J., Beadle-Brown, J., Káňová, S., \& Kittelsaa, A. M. (2017). Change and diversity in community living in Europe-The experiences of persons with disabilities. In R. Halvorsen, B. Hvindem, J. Beadle Brown, M. Biggeri, J. Tøssebro, \& A. Waldschmidt (Eds.), Understanding the lived experiences of persons with disabilities in nine countries. Active citizenship and disability in Europe (Vol. 2, pp. 49-65). London: Routledge.

Söderström, S., \& Tøssebro, J. (2011). Innfridde mål elelr brudte visjoner [Fulfilled ideals or broken promises]. Trondheim, NTNU Social Research. 
Stevens, A. (2004). Closer to home: A critique of British government policy towards accommodating learning disabled people in their own homes. Critical Social Policy, 24(2), 233-254.

Tøssebro, J., Bonfils, I. S., Teittinen, A., Tideman, M., Traustadóttir, R., \& Vesala, H. T. (2012). Normalization fifty years beyond-Current trends in the Nordic
Countries. Journal of Policy and Practice in Intellectual Disabilities, 9, 134-146.

United Nations. (2006). Convention on the rights of persons with disabilities. New York: United Nations.

Wolfensberger, W. (2000). A brief overview of social role valorization. Mental Retardation, 38(2), 105-123.

\section{About the Authors}
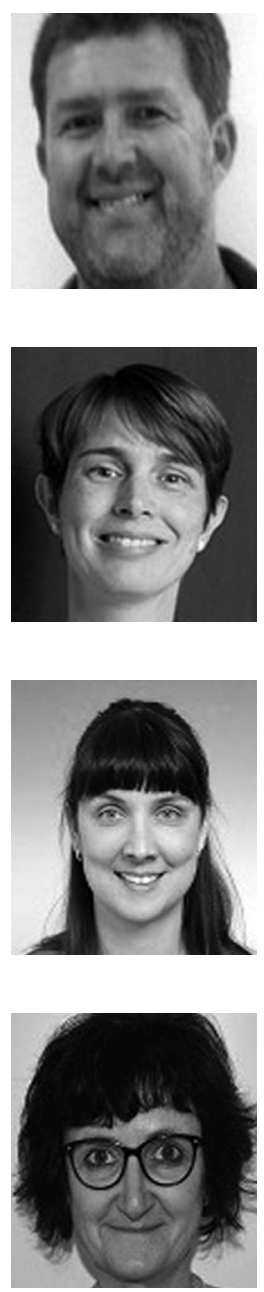

Jan Šiška is Associate Professor at the Faculty of Education, Charles University, and West Bohemia University in the Czech Republic. For last decade, Jan has been serving as a country representative for the Academic Network of European Disability Experts and has conducted research both within the Czech Republic and internationally into deinstitutionalisation and community living, active citizenship, access to education for learners with disabilities, policy development in EU, and staff training, for example in Cambodia, Bhutan, India and Ethiopia. Jan recently served as a lead consultant on special and inclusive education for Federal Ministry of Education in Ethiopia.

Julie Beadle-Brown is Professor in Intellectual and Developmental Disability studies at the Tizard Centre, University of Kent, and Professor in Disability Studies at La Trobe University. Her research interests include deinstitutionalisation and community living, organisational change, person-centred approaches to support, inclusive education and quality of life of children and adults with disabilities and their families. In addition to her research, she spends time working with managers and staff in schools and services, as well as policy makers, NGOS and disabled people's organisations across many countries.

Šárka Káňová is a Researcher and a Senior Lecturer at the Faculty of Education, University of West Bohemia in Pilsen, Czech Republic. Her research interests include the issue of life course of people with disabilities and exploring the possibilities of fulfilling the roles associated with their active citizenship. She has an extensive experience from the third sector environment focused on the area of working with people with disabilities as well as from the local public representation level defending the rights of people in need.

Pavlína Šumníková is an Assistant Professor at the Department of Special Education at the Faculty of Education, Charles University in Prague. She specialises in the education of people with visual and multiple disabilities and has participated in a number of research projects focusing on special education and the situation of people with disabilities, with a particular focus on accessibility, mobility and spatial orientation. 